Reprod. Nutr. Dévelop., 1985, 25 (4 A), 689-703.

\title{
Influence of the gonads and/or of LHRH analogue on gonadotropic function in testosterone-treated or untreated juvenile rainbow trout
}

\author{
Marie-Hélène MAGRI, R. BILLARD, Aline SOLARI $\left({ }^{*}\right)$, Pierrette REINAUD \\ Laboratoire de Physiologie des Poissons, \\ (*) Station de Physiologie animale, \\ I.N.R.A., 78350 Jouy-en-Josas, France.
}

Summary. The influence of the gonads and/or of $\mathrm{LHRH}_{\mathrm{a}}$ on gonadotropic function, and possibly on gonadal development, was studied in juvenile rainbow trout treated with low doses of testosterone or untreated.

Whatever the treatment, all fish of both sexes remained sexually immature, although large individual variations in plasma GTH were observed in all experimental and control groups. This dispersion in the individual values of plasma GTH seemed to be the first sign of an increase in the previously low gonadotropic activity and might announce the beginning of a pubertal period several months before the onset of meiosis in males and of vitellogenesis in females.

Castration did not change the plasma and pituitary GTH values, suggesting that control of the gonadotropic function did not depend mainly on sexual steroids during this period. In our experimental conditions, $\mathrm{LHRH}_{\mathrm{a}}$ administration did not lead to any change in plasma or pituitary levels of GTH. Only the testosterone treatment $(20 \mu \mathrm{g})$ had an effect, causing a higher pituitary GTH load in some fish which was not modified either by castration or by $\mathrm{LHRH}_{\mathrm{a}}$ and decreased with time; neither of these treatments changed the plasma GTH levels. Thus, the fact that the required amount of GTH was not released to initiate early onset of gametogenesis did not seem to be due to a repressive control by the gonads or to the absence of stimulation by an LHRH-like hypothalamic factor. The quantity of GTH accumulated in the pituitary gland and the dose of steroid used have been discussed.

\section{Introduction.}

Only a few studies have been devoted to the gonadotropic activity in sexually immature teleosts from hatching to puberty. According to data collected from control animals in different experiments, the period of immaturity before the first reproductive cycle is characterized by very low or undetectable levels of pituitary and plasma gonadotropin (Salmo salar: Dodd et al., 1978 ; Crim and Peter, 1978 ; Crim and Evans, 1978 ; Stuart-Kregor et al., 1981; Oncorhynchus rhodurus : Ueda et al., 1983 ; Salmo gairdneri : Crim and Evans, 1976, 1979, 1980, 1982, 1983 ; Crim et al., 1981, 1982 ; Anguilla anquilla: Dufour et al., 
$1983 a, b)$. The first sign of a change in gonadotropic activity in connection with the onset of sexual maturation in precocious Atlantic salmon is an increase in pituitary GTH level (Crim and Evans, 1978 ; Dodd et al., 1978 ; Stuart-Kregor et al., 1981); this was confirmed by an ultrastructural study of the pituitary gonadotropic cells (Lindhal, 1980). A parallel increase in the plasma GTH level was low (Crim and Evans, 1978 ; Dodd et al., 1978) or undetectable (StuartKregor et al., 1981).

Crim and Peter (1978) and Crim and Evans (1979) have shown the role of steroids in the modification of this gonadotropic activity. Testosterone implants in the pituitary gland of Atlantic salmon or in the perivisceral cavity of rainbow trout cause a rise in pituitary GTH level in both sexes. This action of steroids on the pituitary gonadotropin content is observed at an early age in rainbow trout (Van den Hurk, 1982) and in European eels (Dufour et al., 1983a, b). The accumulation of GTH in the pituitary gland after a steroid treatment has been confirmed by cytological studies of pituitary gonadotropic cells (Van Overbreeke and McBride, 1971 ; Olivereau and Chambolle, 1978, 1979 ; Sokolowska et al., 1978 ; Pantic and Lovren, 1978 ; Olivereau and Olivereau, 1979a, b; Gielen et al., 1982). Pituitary response may vary according to the type of steroid used and the age and sex of the fish (Crim et al., 1981; Van den Hurk, 1982 ; Dufour et al., 1983a).

In the above studies that mostly used testosterone doses of around $20 \mu \mathrm{g}$. the increase in pituitary GTH level was never accompanied by gonadotropin release in the circulation or by early stimulation of gametogenesis. Only Crim and Evans (1980) observed in vitro a pituitary GTH release from glands of immature animals previously loaded with testosterone in vivo. This release was obtained with LHRH or hypothalamic extracts of immature trout. More recently Crim and Evans (1982, 1983) and Magri et al. (1985) reported the existence of a positive testosterone feedback effect on the gonadotropic function, leading to early stimulation of spermatogenesis when larger doses of testosterone were administered.

In the present study, we examined the possible reasons for this non-release of the GTH accumulated in the pituitary after treatment with low doses $(20 \mu \mathrm{g})$ of testosterone : would it be due to the absence of hypothalamic hormone stimulation and/or to the existence of gonadal secretions suppressing the gonadotropic function?

\section{Material and methods.}

Animals. - The 334 rainbow trout used were 9 months old in November 1981 and weighed 20 to $25 \mathrm{~g}$. They belonged to a fish stock in which $54 \%$ of the males and $9 \%$ of the females had reached puberty at the age of 2 years (winter of 1982-1983) (Chevassus, personal communication). The fish came from the experimental fish farm of "Gournay sur Aronde ". They were brought to the laboratory one month before the experiments began and put in a recycled-water system (Petit, 1974) where they remained until the end of the study. 
Experimental design. - The experiment was carried out for 2 months and in natural conditions of photoperiod and temperature. The fish were given three types of treatment :

- castration in November,

- testosterone implant 4 weeks later,

- repeated injections of LHRH for 3 weeks, 8 days after testosterone implant.

They were sacrificed at the beginning, middle and end of the experiment. The seven experimental groups, given one, two or three treatments, and their corresponding controls are shown in figure 1.

The criteria used were : eviscerated body weight, weight and maturation stage of the gonads, plasma and pituitary GTH levels.

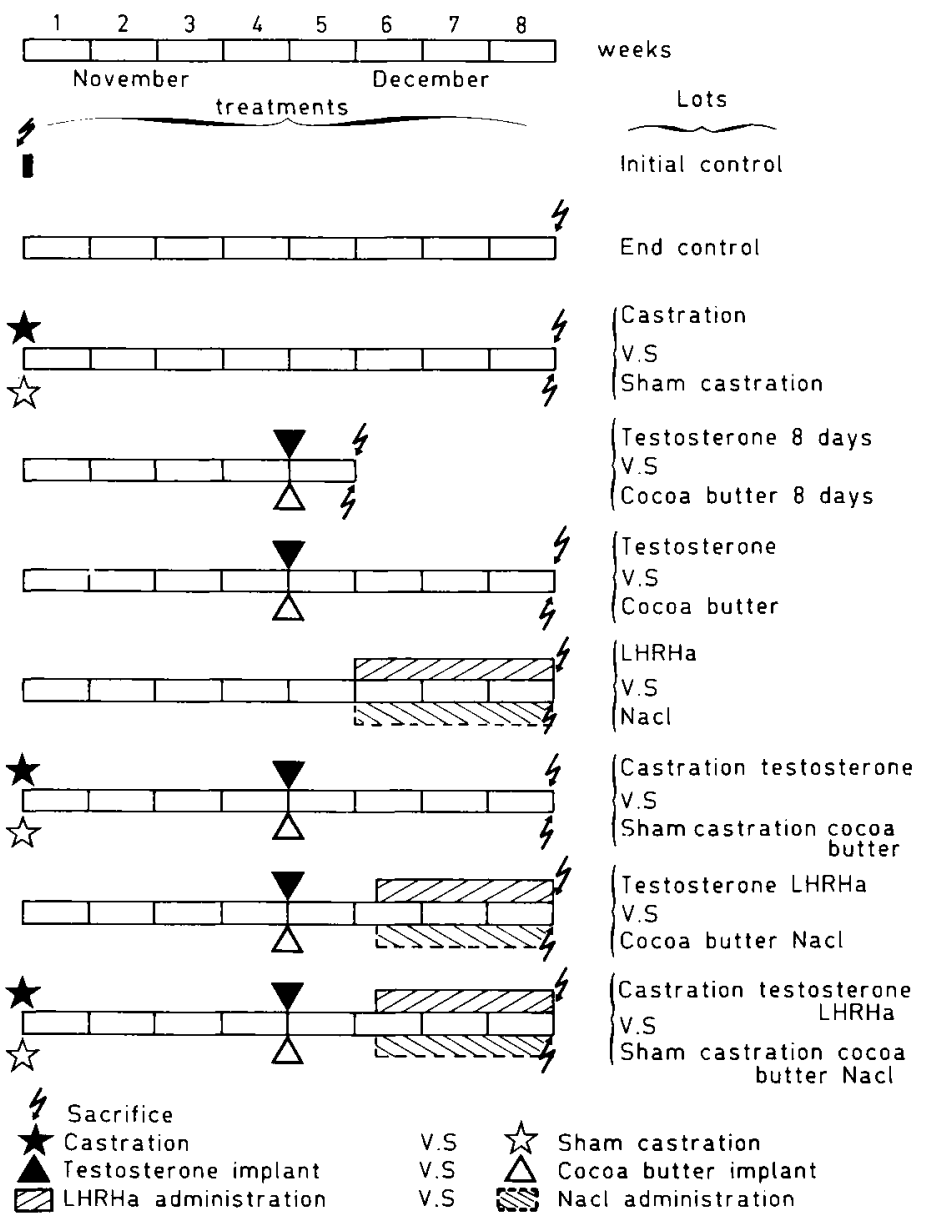

FIG. 1. - Experimental design.

Dates of the various treatments and designations of the 16 control and experimental groups. 
Castration. - Castration was performed according to the method of Billard et al. (1976) using a binocular magnifier. The fish were anaesthetized during the whole operation with a cooled solution of phenoxy-ethanol perfused through the gills. After a ventral incision was made at the level of the pectoral fins, the anterior part of the gonads was detached by small clamps. The gonads were withdrawn backwards and cut off, and the incision was sutured with nylon thread.

In the sham operation the abdominal wall was opened and the gonads examined before the incision was sutured. The incision was then sprayed with antibiotics. The stitches were removed when the edges of the incision had closed.

The fish were starved for one week before and 10 days after the operation. From the time of the operation and until they were completely healed, the trout were kept in tanks of recycled water sterilized by ultra-violet radiation. Total castration was checked at the end of the experiment ( $96 \%$ positive). The females could be distinguished from the males owing to the removal of the adipose fin at the time of castration.

Hormone administration. - Testosterone (17 $\beta$-hydroxyandrostan-4-ene-3-one, Roussel) administered according to methods already described (Billard and Peter, 1977 ; Crim and Evans, 1979), was dissolved in molten pure cocoa butter and injected intraperitoneally into the fish $(20 \mu \mathrm{g}$ of testosterone per fish in a volume of $200 \mu \mathrm{l})$. The control animals received a blank cocoa butter implant. The presence of the implant was checked at the end of the experiment $195 \%$ positive).

We used a lyophilized mammaiian LHRH anaiogue (D-Ala ${ }^{6}$, Des Gly ${ }^{10}$-LHRH ethylamide: Sigma) diluted in a $7 \%$ sodium chloride solution and injected intraperitoneally $(0.025 \mu \mathrm{g} / \mathrm{g}$ body weight in a volume of $200 \mu \mathrm{l})$ three times a week for 3 weeks. The controls received a solution of $7 \% \mathrm{NaCl}$ in the same conditions.

Determination of plasma and pituitary gonadotropin. - Immediately after the pituitaries were taken they were ground in $500 \mu$ l of saline. Samples of pituitary homogenates and blood were stored over crushed ice before centrifugation. Blood plasma and pituitary supernatants were removed and stored at $-20^{\circ} \mathrm{C}$ until analysis. Glycoprotein GTH content was determined by a radioimmunoassay similar to that applied to carp GTH (Breton et al., 1971) using an antibody against pure t-GTH (Breton et al., 1976) and ${ }^{125}$-labelled pure female salmon GTH.

Determination of stage of gonadal development. - After the animals were sacrificed, the gonads were withdrawn and treated according to the usual histological methods, i.e. fixation in Bouin Holland's fluid, then dehydration and embedding in Paraplast. The 5- $\mu \mathrm{m}$ thick sections of the males were stained with Regaud's hematoxylin, orange $G$, aniline blue and those of the females with Heindenhein's Azan (Gabe, 1968).

Statistical analysis. - The mean value, standard deviation, standard error of the mean and coefficient of variation were calculated for each of the four variables measured, i.e. body weight, gonad weight, plasma and pituitary GTH levels. 


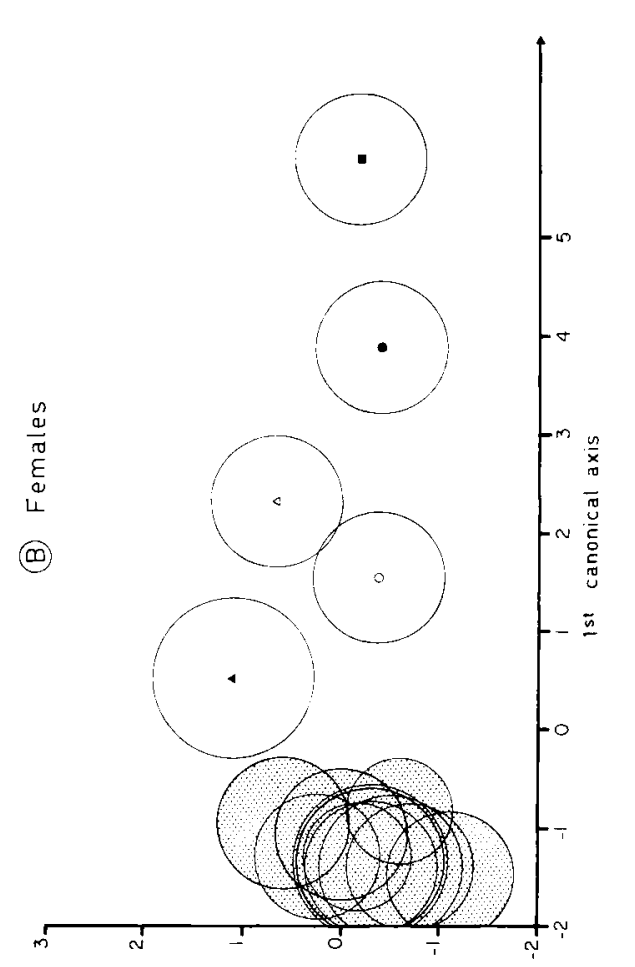

693

ธัฐ

ธ

今.

눵

$\&$

웡

今

की

0.

ఏ 巳

\$

S

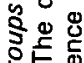

의 옹

웅

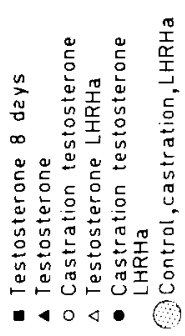

\& 10

合这乒

ㅇํㅇ

용

응

\&

ह 语

\$

ธ文范

(4)

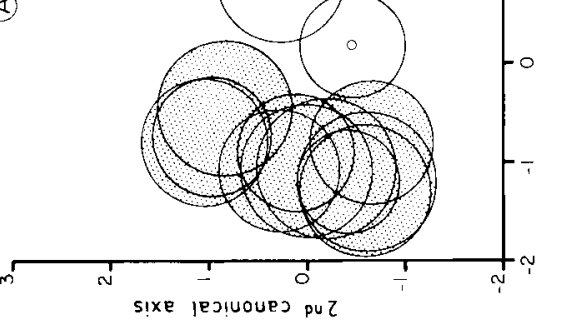

o

ن

몬

Reproduction, nutrition, développernent $n^{\circ} 4 / A,-7$ 
As the number of lots (16) and fish (334) was large (the latter were characterized by four variables), the data were studied by multivariate analysis (Lefèbvre, 1983) based on a simultaneous analysis of all measured variables. The generalized distance $\left(D^{2}\right)$ of Mahalanobis (Solari et al., 1982 ; Lefèbvre, 1983) was used to compare the lots, two by two, by calculating the distance $\left(D^{2}\right)$ between the lots. The significance of the calculated $D^{2}$ was tested by Fisher-Snedecor's Ftest to determine which lots were different from the others and to pool the similar ones. The relative part, or contribution, of the variables in the separation of the lots was expressed in percentage. The distance between the 16 lots was visualized by the mean points of each lot with their 0.95 confidence circle in a plane defined by the first two canonical axes (linear combinations of the 4 biological variables). The more or less marked overlapping of the circles shows the similitude or difference between the lots. In a normal within-lot distribution, $2 / 3$ of the individuals of a lot were located within the confidence circle of radius 1 .

The programs used were developed by Lefèbvre et al. (1981) and the data were processed on a Wang 2200P microcomputer.

\section{Results.}

Because three lots of castrated fish were used, gonad weight was not considered in the first approach involving all the lots (16) and variables (body weight, plasma and pituitary GTH). Two large groups having significant $(P<$ $0.005) D^{2}$ values were found in both males and females. The first canonical axis alone, accounting for 88 (males) and $91 \%$ (females) of the total variability, separated the five testosterone-treated lots from the others (fig. $2 a, b$ ).

The non-overlapping of the different lots along the second canonical axis in the group that was not treated with testosterone (control, $\mathrm{LHRH}_{\mathrm{a}}$ and castration lots) (fig. 2) could be explained by a variability in mean body weight which ranged between 19.0 and $36.0 \mathrm{~g}$ (table $1 \mathrm{a}, \mathrm{b}$ ). The pituitary GTH levels recorded in those lots were always below or equal to $5.7 \mathrm{ng} /$ pituitary (table 1a, b).

The five lots in the testosterone-treated group were discriminated by the first canonical axis owing to significant $\mathrm{D}^{2}$ values (fig. 1a, b). However, a more thorough analysis of the data showed that, contrary to the individuals of the control lots, two-thirds of those of each lot were not located in their 0.67 confidence circle (fig. 3a, b). Indeed, besides the testosterone- $\mathrm{LHRH}_{\mathrm{a}}$ (males) and castration-testosterone- $\mathrm{LHRH}_{\mathrm{a}}$ (females) lots, there were two populations of individuals, one with a pituitary GTH level similar to the controls (on the left of the circle) and one with a higher pituitary GTH level (fig. 2a, b; table 2a, b).

The pituitary GTH level of fish sacrificed 8 days after testosterone implant was significantly $(P<0.005)$ higher than that of the other four lots killed one month later; the pituitary GTH levels of the latter were similar (table $2 a, b$ ).

Pituitary GTH played a very important role in the separation of the lots, its contribution to $D^{2}$ reaching 82 (males) and $91 \%$ (females). The contribution of body weight was 15 (males) and $7 \%$ (females), whereas that of plasma GTH was only $8 \%$ (males and females). 


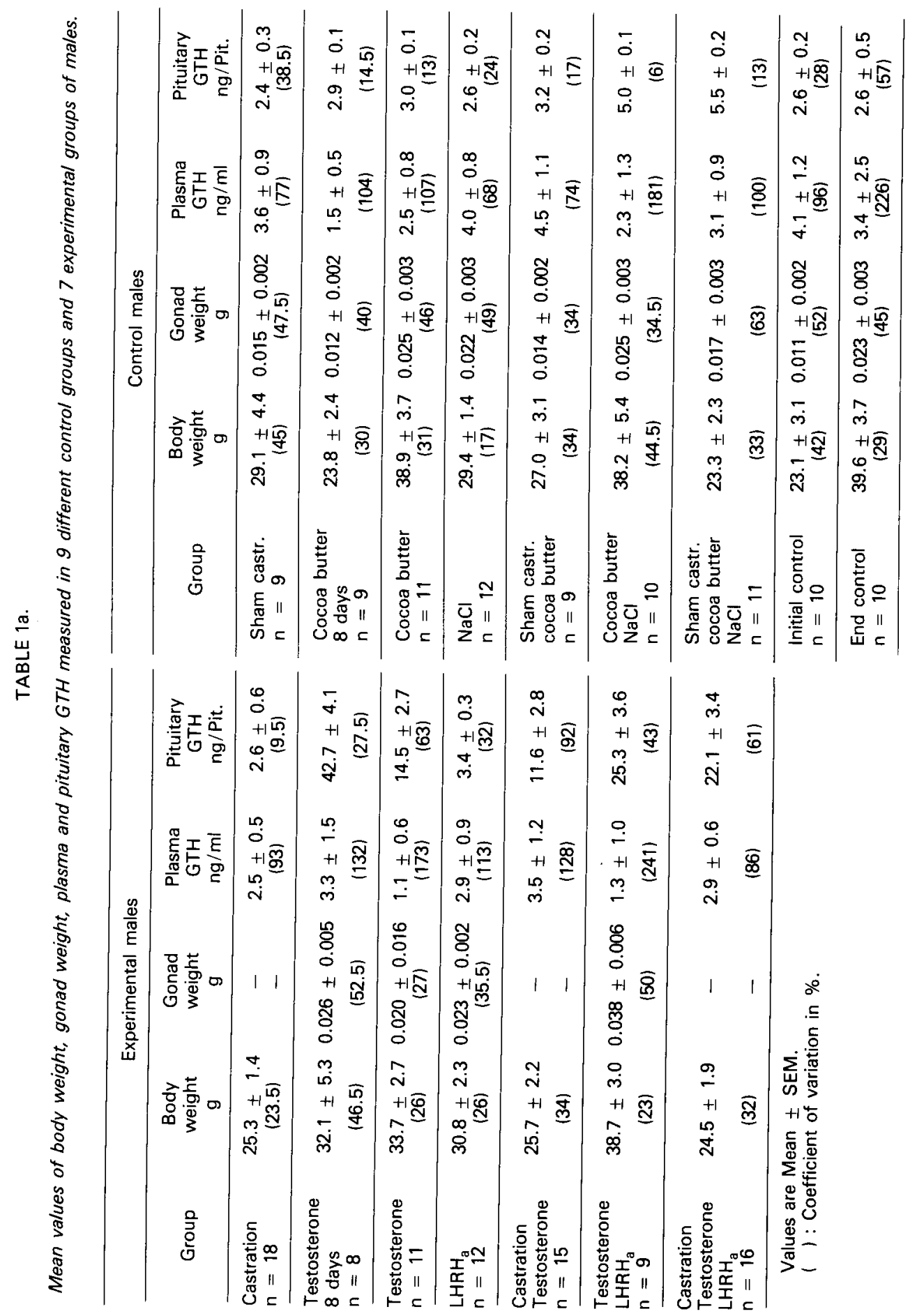




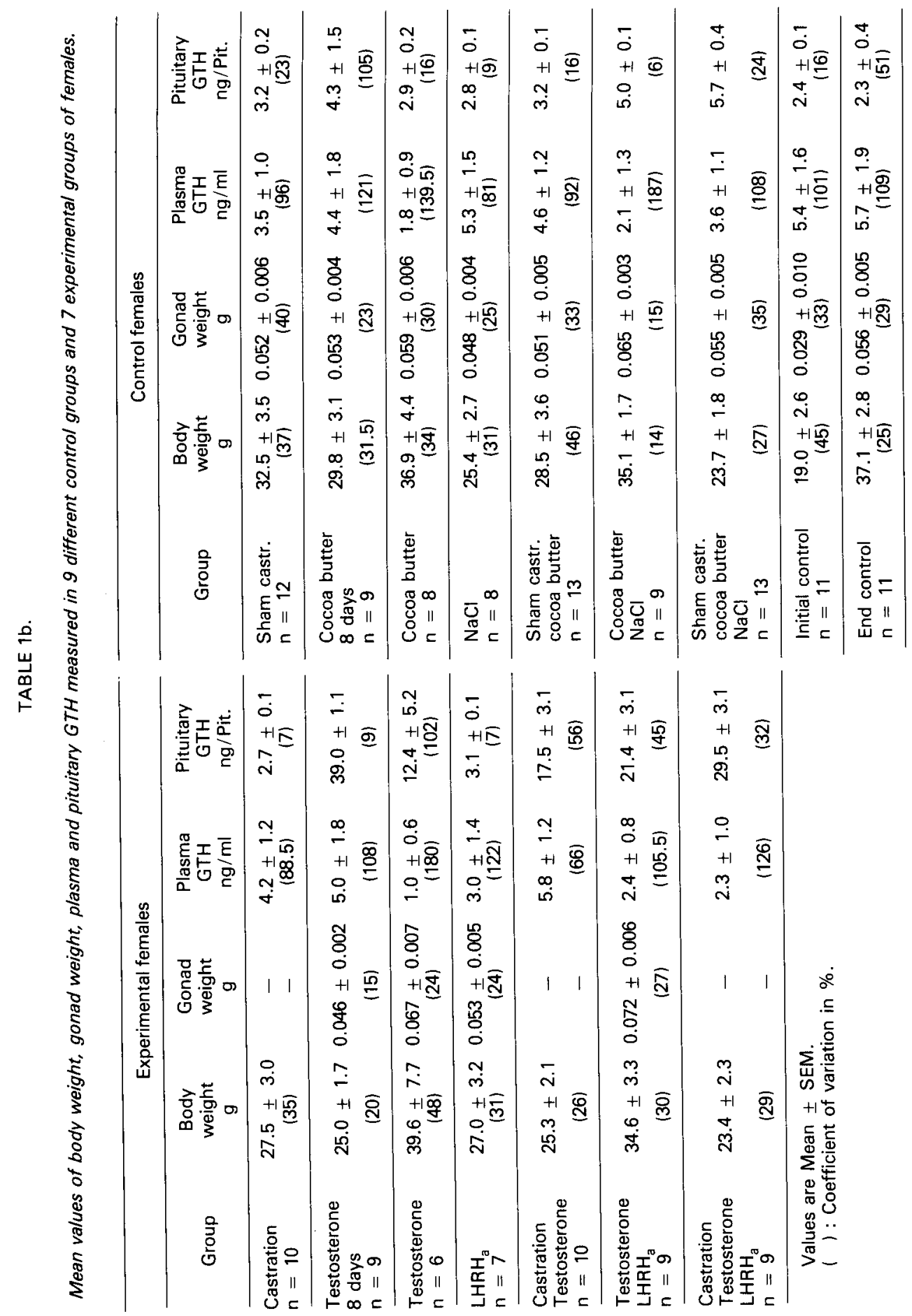


TABLE 2

Mean pituitary GTH level (in ng/pit) of two populations of individuals resulting from multivariate analysis (see fig. 3) in each of the five testosterone-treated groups.

\begin{tabular}{|c|c|c|}
\hline \multicolumn{3}{|c|}{ Males } \\
\hline Group & A & B \\
\hline $\begin{array}{l}\text { Testosterone } \\
8 \text { days }\end{array}$ & $\begin{array}{l}- \\
\langle 0\rangle\end{array}$ & $\begin{array}{c}42.7 \pm 4.1 \\
(8)\end{array}$ \\
\hline Testosterone & $3.9 \underset{\langle 4\rangle}{ \pm} 0.4$ & $20.6 \pm 0.6$ \\
\hline $\begin{array}{l}\text { Castration } \\
\text { Testosterone }\end{array}$ & $\begin{array}{c}2.7 \pm 0.2 \\
(8)\end{array}$ & $\begin{array}{c}21.7 \pm 2.4 \\
\text { (7) }\end{array}$ \\
\hline $\begin{array}{l}\text { Testosterone } \\
\text { LHRH }_{a}\end{array}$ & $\begin{array}{l}- \\
(0)\end{array}$ & $\begin{array}{c}25.3 \pm 3.6 \\
\text { (9) }\end{array}$ \\
\hline $\begin{array}{l}\text { Castration } \\
\text { Testosterone } \\
\text { LHRH }_{a}\end{array}$ & $\begin{array}{c}5.0 \pm 0.1 \\
\text { (4) }\end{array}$ & $\begin{array}{c}27.5 \pm 3.1 \\
(12)\end{array}$ \\
\hline
\end{tabular}

\begin{tabular}{lcc}
\hline \multicolumn{1}{c}{ Gemales } & \\
\hline \multicolumn{1}{c}{ Group } & A & B \\
\hline $\begin{array}{l}\text { Testosterone } \\
8 \text { days }\end{array}$ & - & $39.0 \pm 1.1$ \\
& $(0)$ & $(9)$ \\
\hline Testosterone & $4.9 \pm 1.3$ & $\begin{array}{c}19.9 \pm 8.7 \\
(3)\end{array}$ \\
\hline $\begin{array}{l}\text { Castration } \\
\text { Testosterone }\end{array}$ & $6.3 \pm 1.9$ & $22.3 \pm 2.7$ \\
& $(3)$ & $(7)$ \\
\hline $\begin{array}{l}\text { Testosterone } \\
\text { LHRH }\end{array}$ & $7.2 \pm 0.2$ & $24.9 \pm 2.5$ \\
& $(2)$ & $(7)$ \\
\hline $\begin{array}{l}\text { Castration } \\
\text { Testosterone } \\
\text { LHRH }_{a}\end{array}$ & - & $39.5 \pm 1.0$ \\
\hline
\end{tabular}

Values are Mean \pm SEM.

$($ ): Number of individuals.

A : Pituitary GTH of individuals located within the area of controls ; B : Pituitary GTH of individuals located outside the area of controls.

There was wide individual variability in plasma GTH in all the lots : in the final control lot (males) it ranged between 0 and $25.5 \mathrm{ng} / \mathrm{ml}$ and in the testosterone- 8 day lot (females) between 0.8 and $15.2 \mathrm{ng} / \mathrm{ml}$. This heterogeneity led to coefficients of variation ranging between 66 and $241 \%$ (table 1a, b). There was no correlation between pituitary and plasma levels of GTH.

Histological analysis of gonadal maturation stages evidenced that all the fish were sexually immature, whatever the treatment(s). Male germ cells were represented only by spermatogonia and female cells by oocytes in previtellogenesis. Furthermore, the contributions of gonadal weight to $D^{2}$ were only 4 (males) and $5 \%$ (females) when studied in the 13 lots of uncastrated fish. The observations made with 3 variables were confirmed with 4 variables, i.e. plasma GTH contributed very little (males $1 \%$, females $2 \%$ ), body weight more (males $13 \%$, females $6 \%$ ) and pituitary GTH a great deal (males $82 \%$, females $87 \%$ ).

The pituitary GTH levels of males and females were the same in the control, castration and LHRH lots on the one hand and in the five testosterone-treated lots on the other (table $1 \mathrm{a}, \mathrm{b}$ ).

\section{Discussion.}

Between 9 and 11 months of age, sham operation, injection of $\mathrm{NaCl}$ or of cocoa butter, or a combination of these three treatments, did not lead to any 


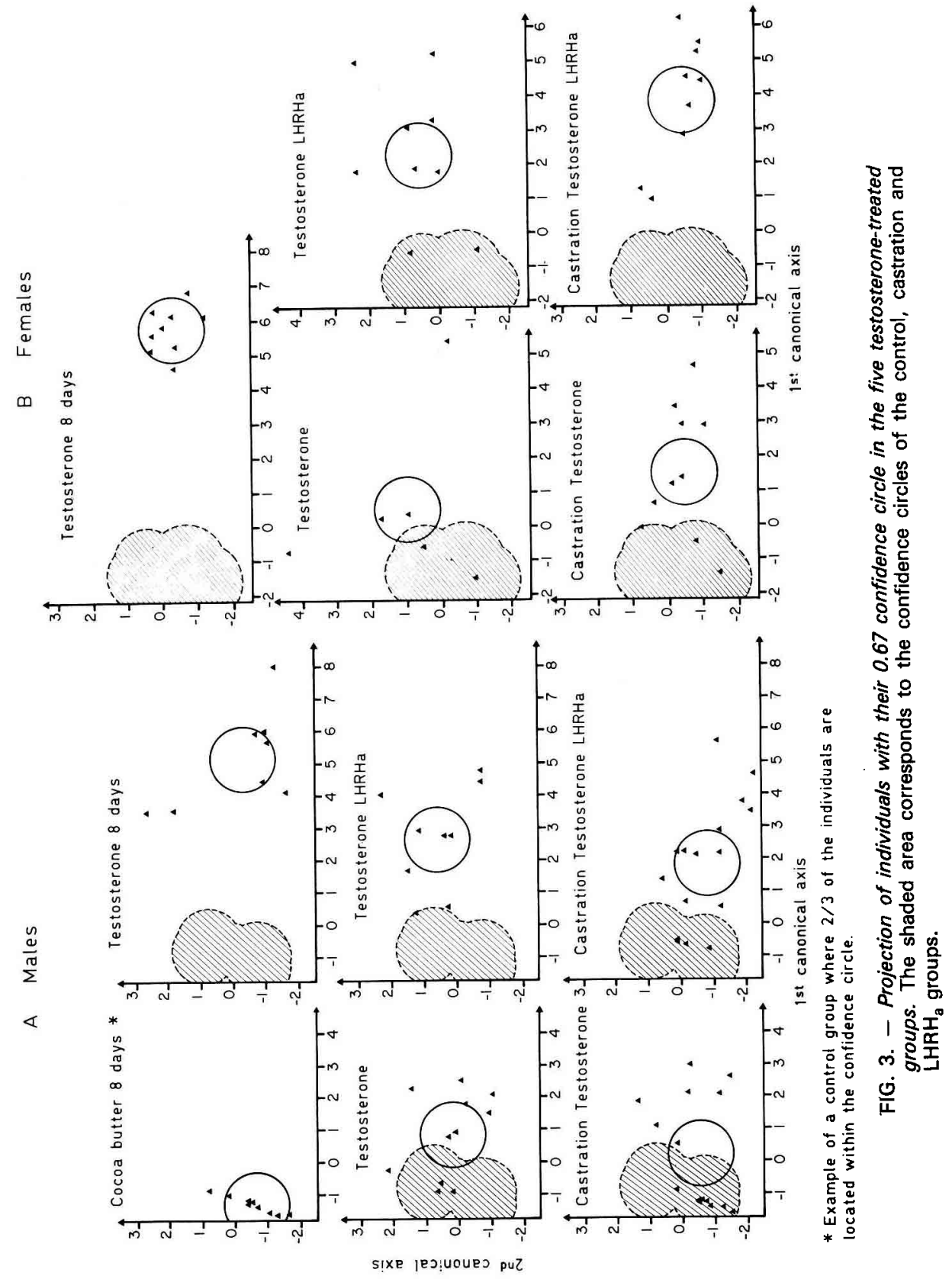


changes in body or gonad weight or in plasma or pituitary GTH levels as compared to the intact controls.

Compared to the other biological variables, the preponderant influence of pituitary GTH in the separation of the testosterone-treated lots from the others was clearly demonstrated by the $D^{2}$ of Mahalanobis.

Our results confirm that gonadotropic activity was low during the period of immaturity (see Introduction). However, large individual variations in plasma GTH levels were recorded during the two experimental months. This heterogeneity has never been reported before in juvenile fish and was independent of pituitary GTH levels. This dispersion of individual values " as an indication of short and aleatory variations in the concentrations of the hormone " (Zohar, 1982) might reflect the possible pulsatile nature of gonadotropic secretion. This would account for the adjustments of the whole hormonal system at the initiation of puberty. We might venture to make an analogy with mammals in which the pubertal period is characterized by a release of gonadotropins increasing in frequency and amplitude (see review by Levasseur, 1977 ; Levasseur and Thibault, 1980). Thus, the pubertal period in rainbow trout, characterized by a higher gonadotropic activity, seems to precede the onset of meiosis in males and of vitellogenesis in females by several months (at the age of 9 months or earlier).

Castration did not cause any increase in mean blood GTH level, confirming the results of Crim et al. (1982) and Gielen et al. (1982), and it did not lead to any decrease in the dispersion of the individual plasma GTH values. These results suggest that it is not the sex steroids (or other gonadal secretions) which repress the gonadotropic function during the juvenile stage. Likewise, the dispersion of the individual values, interpreted as early gonadotropic activity, is independent of gonadal steroid action. The sex steroids only take over the control of the gonadotropic function at full puberty since trout castrated at the age of 6 months showed higher plasma GTH levels after one year than the controls which were in full spermatogenesis at that time (Billard et al., 1982).

In our experimental conditions, $\mathrm{LHRH}_{\mathrm{a}}$ did not cause any modification in plasma and pituitary GTH levels and did not lead to any gonadal development. These observations confirm results obtained with larger doses of $\mathrm{LHRH}_{\mathrm{a}}$ in vitro after short-term hormonal stimulation (Crim and Evans, 1980) or in vivo after longterm stimulation (Crim and Evans, 1983). On the other hand, repeated administration of LHRH in platyfish brings about a more or less early gonadotropic cell differentiation and testis maturation that vary according to animal genotype (Bao and Kallman, 1982). In mammals, the secretion of GNRH is intermittant and this discontinuity is necessary for hormonal action (see review of Knobil, 1980). In prepubertal female macaques the administration of physiological doses of GNRH at suitable intervals leads to early sexual development (Wildt et al., 1980). Because of the contradictory results obtained after the utilization of LHRH in two different species of teleost, it would be necessary to reexamine the dose, time and length of application and the type of GNRH and form of stimulation used. Additional investigations will be required to explain this difference in the results.

The dose of $20 \mu \mathrm{g}$ of testosterone stimulated the synthesis of pituitary GTH 
in all the treated lots without any release of circulatory GTH or stimulation of gametogenesis. This confirms previous observations of Crim and Evans (1979, 1980), Crim et al. (1981) and Gielen et al. $(1982,1983)$ using the same dose. In the present study as in that of Magri et al. (1985) using larger testosterone doses, the treated animals could be distributed into two groups according to pituitary GTH level. These differences in pituitary response to the same hormone dose might be related with age at first maturation (Magri et al., 1985). Fish in which a response was recorded would be the ones maturing early (at 2 years). In these animals pituitary GTH, which was high 8 days after testosterone implant, decreased by half after one month. Our results are contrary to those of Crim and Evans (1979) using the same dose and application time ; they noted a time-dependent increase in pituitary GTH. At the present time, this discrepancy can only be explained by differences in experimental conditions such as temperature and animal age. In our study, this decrease in pituitary gonadotropin with time suggests that the hormone stimulation used $(20 \mu \mathrm{g})$ was not sufficient to maintain GTH synthesis in the pituitary gland.

The decrease in pituitary GTH persisted, the average plasma GTH level was unchanged, and the gonads remained immature independently of repeated $\mathrm{LHRH}_{a}$ injections. In our experimental conditions, $\mathrm{LHRH}_{\mathrm{a}}$ given alone or combined with testosterone was neither a factor of gonadotropin synthesis nor of gonadotropin release. Castration associated with testosterone administration did not change plasma GTH levels. It may be concluded that the non-release of accumulated pituitary GTH observed in all studies using testosterone doses lower than or equal to $20 \mu \mathrm{g}$ did not seem to depend on repressive control by the gonads or on the absence of LHRH-like stimulation. This non-release might be due to the fact that the pituitary load of mobilizable GTH was not large enough to be released into the circulation and induce precocious gametogenesis. However, after an increase in pituitary GTH content owing to larger testosterone doses, GTH is released into the plasma and leads to the onset of gametogenesis (Crim and Evans, 1983 ; Magri et al., 1985). The releasing role of LHRH is then fully expressed since it leads to a faster and sometimes larger increase in plasma GTH level than when testosterone is used alone (Crim and Evans, 1983).

Reçu en mars 1985. Accepté en avril 1985.

Acknowledgements. - The authors wish to thank Mr. Marie and Mr. Le Brenn for their scientific assistance in caring for the fish, Dr. Breton and Mrs. Zambroni for the radioimmunoassays, Mr. Lefebvre and Mrs. Boitard for the statistical analysis and Messrs. Gallé, Slagmulder and Scandolo for the illustrations.

Résumé. Influence des gonades et/ou du $\mathrm{LHRH}_{a}$ sur la fonction gonadotrope chez la truite arc-en-ciel juvénile traitée ou non par la testostérone.

Chez la truite arc-en-ciel juvénile traitée ou non par la testostérone à faible dose, l'influence des gonades et/ou du $\mathrm{LHRH}_{\mathrm{a}}$ est étudiée sur la fonction gonadotrope et éventuellement sur le développement des gonades. 
Quelque soient les traitements et le sexe, tous les animaux restent sexuellement immatures bien que des variations individuelles plasmatiques importantes de la GTH soient observées dans tous les lots témoins et expérimentaux. Cette dispersion des valeurs individuelles de la GTH plasmatique serait les premiers signes d'une augmentation de l'activité gonadotrope jusqu'alors faible et caractériserait le début de la période pubertaire qui précéderait de plusieurs mois l'entrée en méiose des mâles ou le début de la vitellogenèse des fermelles.

La castration ne modifie pas les valeurs plasmatiques et hypophysaires en GTH, indiquant que le contrôle de la fonction gonadotrope durant cette période n'est pas principalement assuré par les stéroïdes sexuels. Dans les conditions expérimentales choisies, le $\mathrm{LHRH}_{\mathrm{a}}$ n'apporte aucun changement plasmatique ou hypophysaire en GTH.

Seul le traitement par la testostérone $(20 \mu \mathrm{g})$ a un effet : il provoque, pour une partie des animaux, une charge hypophysaire en GTH plus élevée qui n'est modifiée ni par la castration ni par le $\mathrm{LHRH}_{\mathrm{a}}$ et qui diminue en fonction du temps. La castration ou le $\mathrm{LHRH}_{\mathrm{a}}$ ne modifient pas les teneurs en GTH plasmatique.

La non-libération d'un niveau de GTH convenable qui permettrait un déclenchement précoce de la gamétogenèse ne serait donc pas due à une répression des gonades ou à l'absence de stimulation par un facteur hypothalamique de type LHRH. La quantité de GTH accumulée dans l'hypophyse et la dose de stéroïde utilisée sont discutées.

\section{References}

BAO I. Y., KALLMAN K. D., 1982. Genetic control of the hypothalamo-pituitary axis and the effect of hybridization on sexual maturation (Xiphophorus, pisces, Poeciliidae). J. exp. Zool., 220, 297-309.

BILLARD R., PETER R. E., 1977. Gonadotropin release after implantation of anti-estrogens in the pituitary and hypothalamus of goldfish, Carassius auratus. Gen. comp. Endocrinol., 32, 213220.

BILLARD R., RICHARD M., BRETON B., 1976. Stimulation de la sécrétion gonadotrope hypophysaire après castration chez la Truite arc-en-ciel; variation de la réponse au cours du cycle reproducteur. C.R. Acad. Sci. Paris, Sér. D., 283, 171-174.

BILLARD R., CRIM L. W., PETER R. E., BRETON B., 1982. Long-term changes in plasma and pituitary GTH after castration of rainbow trout at an immature stage, p. 50 . In C. J. J. RICHTER, H. J. Th. GOOS, Proceed. int. Symp. Reproductive physiology of fish, Wageningen, Netherlands.

BRETON B., JALABERT B., REINAUD P., 1976. Purification of gonadotropin from rainbow trout (Salmo gairdneri R.) pituitary glands. Ann. Biol. anim. Bioch. Biophys., 16, 25-36.

BRETON B., KANN G., BURZAWA-GÉRARD E., BILLARD R., 1971. Dosage radio-immunologique d'une hormone gonadotrope de carpe (Cyprinus carpio L.) C.R. Acad. Sci. Paris, Sér. D, 272, 1515-1517.

CRIM L. W., EVANS D. M., 1976. Gonadotropic hormone treatment of rainbow trout /Salmo gairdneri) ; plasma hormone profile following a single injection. J. Fish. Res. Board Can., 33, 2841-2844.

CRIM L. W., EVANS D. M., 1978. Seasonal levels of pituitary and plasma gonadotropin in male and female Atlantic salmon parr. Can. J. Zool., 56, 1550-1555.

CRIM L. W., EVANS D. M., 1979. Stimulation of pituitary gonadotropin by testosterone in juvenile rainbow trout Salmo gairdneri. Gen. comp. Endocrinol., 37, 192-196.

CRIM L. W., EVANS D. M., 1980. LH-RH-stimulated gonadotropin release from the rainbow trout pituitary gland : an in vitro assay for detection of teleost gonadotropin-releasing factor(s). Gen. comp. Endocrinol., 40, 283-290.

CRIM L. W., EVANS D. M., 1982. Positive steroid feedback on gonadotropic hormone in juvenile rainbow trout: evidence of gonadotropin synthesis and release following testosterone administration via silastic capsules, p. 23. In C. J. J. RICHTER, H. J. Th. GOOS, Proceed. int. Symp. Reproductive physiology of fish, Wageningen, Netherlands. 
CRIM L. W., EVANS D. M., 1983. Influence of testosterone and/or luteinizing hormone releasing hormone analogue on precocious sexual development in the juvenile rainbow trout. Biol. Reprod., 29, 137-142.

CRIM L. W., PETER R. E., 1978. The influence of testosterone implantation in the brain and pituitary on pituitary gonadotropin levels in Atlantic salmon parr. Ann. Biol. anim. Bioch. Biophys., 18, 689-694.

CRIM L. W., PETER R. E., BILLARD R., 1981. Onset of gonadotropic hormone accumulation in the immature trout pituitary gland in response to estrogen or aromatizable androgen steroid hormones. Gen. comp. Endocrinol., 44, 374-381.

CRIM L. W., BILLARD R., GENGE P. D., IDLER D. R., 1982. The influence of immature gonads on onset of gonadotropic hormone accumulation in the juvenile rainbow trout pituitary gland. Gen. comp. Endocrinol., 48, 161-166.

DODD J. M., STUART-KREGOR P. A. C., SUMPTER J. P., CRIM L. W., PETER R. E., 1978. Premature sexual maturation in the Atlantic salmon Salmon salar L., 101-104. In P. J. GAILLARD, H. H. BOER, Comparative endocrinology. Elsevier/North Holland biomed., Press, Amsterdam.

DUFOUR S., DELERUE-LE BELLE N., FONTAINE Y. A., 1983a. Effects of steroid hormones on pituitary immunoreactive gonadotropin in European freshwater eel Anguilla anguilla L. Gen. comp. Endocrinol., 52, 190-197.

DUFOUR S., DELERUE-LE BELLE N., FONTAINE Y. A., 1983b. Development of a heterologous radioimmunoassay for eel (Anguilla anguilla) gonadotropin. Gen. comp. Endocrinol., 49. 404-413.

GABE M., 1968. Techniques histologiques. Masson Ed., Paris, 1113 pp.

GIELEN J. Th., GOOS H. J. Th., PEUTE J., VAN DEN BOSCH R. A., VAN OORDT P. G. W. J., 1982. The brain-pituitary-gonadal axis in the rainbow trout, Salmo gairdneri: gonadal hormones and the maturation of gonadotropic cells. Cell Tiss. Res., 225, 45-56.

GIELEN J. Th., GOOS H. J. Th., 1983. The brain-pituitary-gonadal axis in the rainbow trout, Salmo gairdneri. II. Direct effect of gonadal steroids on the gonadotropic cells. Cell Tissue Res., 233, 377-388.

KNOBIL E., 1980. The neuroendocrine control of the menstrual cycle. Rec. Progr. Horm. Res., $36,53-88$.

LEFĖBVRE J., 1983. Introduction aux analyses statistiques multidimensionnelles. Masson, Paris, $275 \mathrm{pp}$. ( $3^{\circ}$ éd., augmentée d'exemples d'applications).

LEFĖBVRE J., BOITARD M., REY J. F., 1981. Logiciels d'analyses statistiques multidimensionnelles sur micro-ordinateurs. Masson, Paris, $148 \mathrm{pp}$.

LEVASSEUR M. C., 1977. Thoughts on puberty. Initiation of the gonadotropic function. Ann. Biol. anim. Biochim. Biophys., 17, 345-361.

LEVASSEUR M. C., THIBAULT C., 1980. De la puberté à la sénescence. La fécondité chez l'Homme et les autres Mammifères. Collection "INRA Actualités scientifiques et agronomiques", Masson Ed., 120 p.

LINDHAL K., 1980. The gonadotropic cell in parr, precocious parr male and smolt of the Atlantic salmon, Salmo salar. An immunocytological, light- and electron microscopical study. Acta zool. (stock. H.), 61, 117-125.

MAGRI M. H., SOLARI A., BILLARD R., REINAUD P., 1985. Influence of testosterone on precocious sexual development in immature rainbow trout. Gen. comp. Endocrinol., 57, 411-421.

OLIVEREAU M., CHAMBOLLE P., 1978. Ultrastructure des cellules gonadotropes de l'Anguille normale et après injection d'œstradiol. C.R. Acad. Sci. Paris, 287 D, 1409-1412.

OLIVEREAU M., CHAMBOLLE P., 1979. Ultrastructure of gonadotrophs in the eel following oestradiol treatment. Proc. ind. nat. Sci. Acad., B 45, 478-482.

OLIVEREAU M., OLIVEREAU J., 1979a. Effect of estradiol-17 $\beta$ on the cytology of the liver, gonads and pituitary, and on plasma electrolytes in the female freshwater eel. Cell Tissue Res., 199. 431-454.

OLIVEREAU M., OLIVEREAU J., 1979b. Estradiol positive feedback on gonadotropic (GTH) cells in freshwater male silver eels. Gen. comp. Endocrinol., 39, 247-261.

PANTIC V., LOVREN M., 1978. The effects of female gonadal steroids on carp pituitary gonadotropic cells and oogenesis. Folia anat. iugos/av., VII, 25-34. 
PETIT J., 1974. Recyclage et épuration en pisciculture : étude théorique et bibliographique. Actes Coll. CNEXO, $\mathrm{n}^{\circ} 1,445-467$.

SOKOLOWSKA M., EPLER P., BIENIARZ K., 1978. The histological picture of the hypothalamus (the nucleus preopticus) and hypophysis in male Anguilla anguilla L. treated with hormones. J. Fish Biol., 12, 1-4.

SOLARI A., LEFĖBVRE J., CAILLOL M., 1982. Application des méthodes d'analyses multidimensionnelles à l'étude des variations du comportement sexuel et des stéroïdes ovariens chez la lapine pseudogestante. Actes 10 Coll. Informatique et biosphère, 169-187.

STUART-KREGOR P. A. C., SUMPTER J. P., DODD J. M., 1981. The involvement of gonadotropin and sex steroids in the control of reproduction in the parr and adults of Atlantic salmon, Salmo salar L. J. Fish Biol., 18, 59-72.

UEDA H., NAGAHAMA Y., TASHIRO F., CRIM L. W., 1983. Some endocrine aspects of precocious sexual maturation in the amago salmon Oncorhynchus rhodurus. Bull. jap. Soc. Sci. Fish., 49, 587-596.

VAN DEN HURK R., 1982. Effects of steroids on gonadotropic (GTH) cells in the pituitary of rainbow trout, Salmo gairdneri, shortly after hatching. Cell. Tissue Res., 224, 361-368.

VAN OVERBREEKE A. D., McBRIDE J. R., 1971. Histological effects of 11-ketotestosterone, $17 \alpha$-methyltestosterone, estradiol, estradiol cypionate and cortisol on the interrenal tissue, thyroid gland and pituitary gland of gonadectomized sockeye salmon Oncorhynchus nerka. $J$. Fish. Res. Board Can., 28, 477-484.

WILDT L., MARSHALL G., KNOBIL E., 1980. Experimental induction of puberty in the infantile female rhesus monkey. Science, 207, 1373-1375.

ZOHAR Y., 1982. L'évolution de la pulsatilité et des cycles nycthéméraux de la sécrétion gonadotrope chez la truite arc-en-ciel femelle, en relation avec le cycle sexuel annuel et par rapport à l'activité stéroïdogène de l'ovaire. Thèse Doct. Etat, Univ. Paris VI. 